\title{
HUBUNGAN PENYAKIT KECACINGAN DENGAN STATUS GIZI ANAK PADA SEKOLAH DASAR MUHAMMADIYAH JAMPU KECAMATAN LANRISANG KABUPATEN PINRANG
}

\section{The Relationship between Helminthiasis and the nutritional status of Children in Muhammadiyah Elementary School of Jampu}

\author{
Dewi Astuti, Erna Magga, Abidin Djalla \\ Program Studi Kesehatan Masyarakat Fakultas Ilmu Kesehatan Universitas Muhammadiyah Parepare \\ ( dwiastutiarjumeini@yahoo.co.id )
}

\begin{abstract}
ABSTRAK
Pada tahun 2017 jumlah kasus penderita cacingan di Kabupaten Pinrang sebanyak 366 kasus. Kecamatan Lanrisang merupakan kecamatan dengan jumlah penderita cacingan tertinggi selama tahun 2017 dengan 125 kasus. Usia yang masih rentan untuk terinfeksi cacingan terdapat pada kelompok usia sekolah yaitu 6-12 tahun, oleh karena itu penelitian ini akan fokus pada kelompok usia Sekolah Dasar. Tujuan penelitian ini untuk menjelaskan hubungan antara status gizi dengan penyakit kecacingan pada siswa SD Muhammadiyah Jampu Kecamatan Lanrisang Kabupaten Pinrang. Jenis penelitian ini adalah survei analitik dengan pendekatan study, instrument penelitian yang digunakan adalah uji lab dan kuesioner. Populasi dalam penelitian ini adalah seluruh siswa kelas 1, 2 dan 3 di Sekolah Dasar Muhammadiyah Jampu Kecamatan Lanrisang Kabupaten Pinrang yang berjumlah 26 siswa. Teknik pengambilan sampel dilakukan dengan total sampling. Analisis data dilakukan dengan analisis univariat dan bivariat. Hasil penelitian menunjukkan bahwa terdapat 19 siswa $(73,3 \%)$ dengan status gizi normal dan 7 siswa (26,3\%) dengan status gizi kurus. Jumlah siswa yang positif cacingan sebanyak 6 siswa $(23,7)$ dan yang negatif sebanyak 20 siswa 76,3\%). Dari uji chi-square yang dilakukan menunjukkan bahwa terdapat hubungan antara status gizi dengan penyakit kecacingan siswa pada SD Muhammadiyah Jampu Kecamatan Lanrisang Kabupaten Pinrang.
\end{abstract}

\section{Kata Kunci : Status gizi, kecacingan}

\begin{abstract}
In 2017 the number of cases of worm sufferers in Pinrang District was 366 cases. Lanrisang Subdistrict is the sub-district with the highest number of worm sufferers in 2017 with 125 cases. Age that is still vulnerable to change at school age is 6-12 years, therefore it will focus on elementary school lessons. The purpose of this study was to explain the relationship between nutritional status with helminthiasis in students of SD Muhammadiyah Jampu Kecamatan Lanrisang Kabupaten Pinrang. This type of research is analytic survey with study approach, the research instrument used is laboratory test and questionnaire. The population in this study were all students in grades 1, 2 and 3 in SD Muhammadiyah Jampu Kecamatan Lanrisang Kabupaten Pinrang, which were empty of 26 students. The sampling technique is done by total sampling. Data analysis was carried out by univariate and bivariate analysis. The results showed that there were 19 students (73.3\%) with normal nutritional status and 7 students $(26.3 \%)$ with thin nutritional status. The number of positive students was 26 students (23.7) and the negative were 20 students 76.3\%). The chi-square test showed that there was a relationship between nutritional status and worm disease in students at SD Muhammadiyah Jampu Kecamatan Lanrisang Kabupaten Pinrang.
\end{abstract}

Keywords : Nutritional status, helminthiasis 


\section{PENDAHULUAN}

Keadaan gizi adalah keadaan akibat dari keseimbangan antara konsumsi dan penyerapan zat gizi dan penggunaan zat-zat gizi tersebut, atau keadaan fisiologik akibat dari tersedianya zat gizi dalam seluler tubuh. Status gizi adalah keadaan tubuh sebagai akibat dari pemakaian, penyerapan dan penggunaan makanan. Makanan yang memenuhi gizi tubuh, umumnya membawa ke status gizi memuaskan. Zat gizi diartikan sebagai zat kimia yang terdapat dalam makanan yang diperlukan manusia untuk memelihara dan meningkatkan kesehatan. Sampai saat ini dikenal kurang lebih 45 jenis zat gizi dan sejak akhir tahun 1980an dikelompokkan keadaan zat gizi makro yaitu zat gizi sumber energi berupa karbohidrat, lemak, dan protein dan zat gizi mikro yaitu vitamin dan mineral. ${ }^{1}$

Berdasarkan hasil Riset Kesehatan dasar (RISKESDAS) Tahun 2007 menunjukkan bahwa Prevalensi nasional Anak Usia Sekolah Kurus (laki-laki) adalah 13,3\%, sedangkan prevalensi nasional Anak Usia Sekolah Kurus (Perempuan) adalah 10,9\%. Sebanyak 19 provinsi mempunyai prevalensi Anak Usia Sekolah Kurus diatas prevalensi nasional, yaitu di Aceh, Riau, Jambi, Sumatera Selatan, Lampung, Kepulauan Riau, DKI Jakarta, Jawa Tengah, Banten, Nusa Tenggara Barat, Nusa Tenggara Timur, Kalimantan Barat, Kalimantan Tengah, Kalimantan
Selatan, Kalimantan Timur, Sulawesi Selatan, Sulawesi Tenggara, Sulawesi Barat, dan Maluku. ${ }^{2}$

Kemudian RISKESDAS Tahun 2013 menunjukkan prevalensi kurus (menurut IMT/U) pada anak umur 5-12 tahun adalah 11.2 persen, terdiri dari 4,0 persen sangat kurus dan 7,2 persen kurus. Prevalensi sangat kurus paling rendah di Bali (2,3\%) dan paling tinggi di Nusa Tenggara Timur (7,8\%). Dari hasil RISKESDAS tahun 2013 menunjukkan bahwa terdapat penurunan prevalensi kurus dari tahun 2007 ke tahun $2013 .^{3}$

Kelompok anak usia sekolah dasar adalah salah satu kelompok umur yang rentan terhadap penyakit-penyakit kekurangan gizi, oleh sebab itu indikator yang paling baik untuk mengukur status gizi masyarakat adalah dengan melalui pengukuran status gizi. Kurang gizi pada anak tidak mudah dikenali oleh pemerintah atau masyarakat bahkan keluarga. Salah satu penyakit yang menyebabkan anak mengalami kekurangan gizi adalah penyakit kecacingan.

Cacingan secara kumulatif pada manusia dapat menimbulkan kehilangan zat gizi berupa karbohidrat dan protein serta kehilangan darah, sehingga dapat menurunkan produktivitas kerja. Kecacingan juga dapat menghambat perkembangan fisik. Kecacingan juga dapat menyebabkan menurunnya ketahanan tubuh sehingga mudah terkena penyakit lainnya. ${ }^{4}$ 
Sebelum anak terkena cacingan, terlebih dahulu telur cacing keluar dari perut manusia bersama kotoran atau faces. Jika limbah manusia itu dialirkan ke sungai atau got, maka setiap tetes air akan terkontaminasi telur cacing. Jika air yang telah tercemar dipakai oleh orang lain untuk menyirami tanaman atau aspal jalan, telur-telur itu naik ke darat. Begitu air mengering, mereka menempel pada butiran debu. Telur lainnya terbang ke tempat-tempat yang sering dipegang tangan manusia. ${ }^{5}$

Setelah terinfeksi akan mengalami kekurangan hemoglobin (Hb) hingga 12 gr persen dan akan berdampak terhadap kemampuan darah membawa oksigen ke berbagai jaringan tubuh, termasuk ke otak. Akibatnya, penderita cacingan terserang penurunan daya tahan tubuh serta metabolisme jaringan otak. Bahkan dalam jangka panjang, penderita akan mengalami kelemahan fisik dan intelektualitas. Jika pasien sudah terinfeksi cacing, baisanya akan menunjukkan gejala keterlambatan fisik, mental dan seksual. ${ }^{6}$

Cacing dapat masuk ke tubuh manusia melalui kontak langsung antara kulit dengan tanah atau air yang kotor, di mana terdapat telur cacing. Setelah menembus kulit, maka cacing akan masuk ke pembuluh darah balik (vena), lalu menuju ke organ dalam tubuh manusia. Cacing kerap berkembang biak dan berkoloni di dalam usus. Di sana, cacing akan menggigit dinding usus untuk mengambil nutrisi yang masuk di dalam tubuh. karbohidrat dan berbagai protein yang harusnya dicerna tubuh akan diambil oleh cacing-cacing dalam perut, kondisi ini akan membahayakan, terutama bagi anak yang berada pada periode emas pertumbuhannya.

Penyakit cacingan dapat menyebabkan kekurangan gizi karena semua nutrisi diserap oleh cacing akan membuat perkembangan mental dan fisik anak menjadi terganggu, membuat anak menjadi mudah sakit karena penurunan sistem imunitasnya, stunting atau fisik anak menjadi lebih pendek dan kecil dari teman seusianya, berkurangnya kecerdasaan anak serta pada beberapa kasus juga dapat menyebabkan kematian pada anak. Kematian anak akibat cacingan biasanya dikarenakan sudah terlalu banyaknya cacing di dalam tubuh si kecil, hingga membuat cacing berjelajah ke organ tubuh yang lain seperti paru-paru dan lainnya.

Dari hasil observasi yang penulis lakukan pada Dinas Kesehatan Kabupaten Pinrang maka penulis mendapatkan informasi bahwa pada tahun 2017 jumlah kasus penderita cacingan di Kabupaten Pinrang sebanyak 366 kasus. Kecamatan Lanrisang merupakan kecamatan dengan jumlah penderita cacingan tertinggi selama tahun 2017 dengan 125 kasus. Usia yang masih rentan untuk terinfeksi cacingan terdapat pada kelompok usia sekolah yaitu 6-12 tahun, oleh karena itu penelitian ini akan fokus pada kelompok usia Sekolah Dasar. 
Berdasarkan penjelasan tersebut maka penulis tertarik untuk melakukan penelitian terkait dengan variabel penyakit cacingan dan status gizi anak dengan judul "Hubungan Penyakit Cacingan Dengan Status Gizi Anak Pada SD Muhammadiyah Jampu Kecamatan Lanrisang Kabupaten Pinrang"

\section{BAHAN DAN METODE}

Penelitian ini adalah penelitian dengan metode Cross Sectional Study. Populasi dalam penelitian ini adalah seluruh siswa kelas 1, 2, dan 3 sebanyak 26 orang. Pengambilan sampel pada penelitian ini menggunakan metode total sampling. Variabel independen dalam penelitian ini adalah penyakit cacingan sedangkan variabel dependennya adalah status gizi.

Instrument dalam penelitian ini untuk variabel penyakit cacingan berupa data jumlah anak yang terjangkit penyakit cacingan di SD Muhammadiyah Jampu Kecamatan Lanrisang Kabupaten Pinrang sedangkan instrument untuk variabel status gizi menggunakan kuesioner yang akan disebar kepada para responden.

\section{HASIL}

Hasil penelitian pada tabel 1 menunjukkan bahwa dari 26 responden terdapat 15 orang $(57,7 \%)$ yang berjenis kelamin laki-laki, dan jenis kelamin perempuan sebanyak 11 orang $(42,3 \%)$, sedangkan berdasarkan umur responden yang berumur 8 tahun sebanyak 6 orang $(23,1 \%)$ dan yang berumur 10 tahun ada sebanyak 8 orang $(30,8 \%)$.

Hasil penelitian pada tabel 2 menunjukkan berdasarkan kelompok status gizi bahwa dari 26 responden yang diteliti sebanyak 19 orang $(73,1 \%)$ yang memiliki status gizi normal dan siswa dengan status gizi kurus sebanyak 7 orang $(26,9 \%)$ siswa. Sedangkan dari hasil uji fases terhadap 26 siswa yang diteliti sebanyak 20 orang $(76,9 \%)$ yang teridentifikasi negatif terinfeksi penyakit kecacingan sedangkan sebanyak 6 orang $(23,1 \%)$ teridentifikasi positif terinfeksi penyakit kecacingan.

Dapat dilihat distribusi jawaban responden pada tabel 3 yang menunjukkan bahwa sebanyak $22(84,5 \%)$ responden mengkonsumsi air minum yang telah matang, sebanyak $8(30,9 \%)$ responden yang rutin mengkonsumsi obat cacingan per 6 bulan sekali, sebanyak $23(88,2 \%)$ orang tua siswa memperhatikan kebersihan anaknya, sebanyak 13 (50\%) responden mempunyai tempat tinggal diwilayah pesisir pantai, sebanyak 21 $(80,9 \%)$ responden tinggal ditempat lingkungan yang bersih, seluruh responden menyatakan bahwa mencuci tangan terlebih dahulu sebelum makan dan minum, sebanyak $21(80,9 \%)$ responden mengganti pakaian usai beraktivitas, sebanyak $24(92,8 \%)$ responden mandi 2 kali dalam sehari, sebanyak 19 $(73,7 \%)$ responden memperhatikan kebersihan makanan dan minumannya, kemudian terdapat 
$15(57,2 \%)$ responden yang menggunakan sandal saat keluar rumah bermain, sementara itu ada $20(76,3 \%)$ mencuci tangan setelah bermain dan terdapat $19(73,7 \%)$ responden yang memperhatikan kebersihan pakaiannya.

Hasil penelitian pada tabel 4 menunjukkan bahwa siswa dengan status gizi kurus $83,3 \%$ positif terinfeksi penyakit kecacingan sedangkan siswa dengan status gizi normal mayoritas negatif terinfeksi penyakit kecacingan sebesar 90\%. Dari analisis tersebut menunjukkan bahwa siswa dengan status gizi kurus lebih banyak yang terinfeksi penyakit kecacingan dibandingkan dengan siswa dengan status gizi normal.

\section{PEMBAHASAN}

Berdasarkan hasil penelitian yang menunjukkan bahwa nilai $p$ sebesar 0,001 sehingga jika dibandingkan dengan taraf signifikan $5 \% \quad(0,05)$ maka hasilnya dinyatakan bahwa terdapat hubungan antara status gizi dengan penyakit kecacingan pada siswa SD Muhammadiyah Jampu Kecamatan Lanrisang Kabupaten Pinrang.

Kecacingan merupakan penyakit infeksi yang disebabkan oleh parasit berupa cacing. Dimana dapat terjadi infestasi ringan maupun infestasi berat. Infeksi kecacingan adalah infeksi yang disebabkan oleh cacing kelas nematode usus khususnya yang penularan melalui tanah, diantaranya Ascaris lumbricoides, Trichuri strichiura, dan cacing tambang (Ancylostoma duodenale dan Necator americanus) dan Strongyloides stercoralis. ${ }^{7}$

Kecacingan jarang sekali menyebabkan kematian secara langsung, namun sangat mempengaruhi kualitas hidup penderitanya. Kecacingan dapat mengakibatkan menurunnya kondisi kesehatan, gizi, kecerdasan dan produktivitas penderita sehingga secara ekonomi dapat menyebabkan banyak kerugian yang pada akhirnya dapat menurunkan kualitas sumber daya manusia. Infeksi cacing pada manusia dapat dipengaruhi oleh perilaku, lingkungan tempat tinggal dan manipulasinya terhadap lingkungan. ${ }^{8}$

Untuk menentukan diagnosis pasti infeksi cacing, diperlukan pemeriksaan laboratorik untuk menemukan parasit cacing baik yang dewasa, telur maupun stadium larvanya. Agar usaha tersebut berhasil memuaskan, maka selain kemampuan untuk mengenal morfologi cacing dengan benar, bahan-bahan untuk pemeriksaan hendaknya diupayakan tersedia dalam keadaan yang baik, danparasit dapat diperoleh dalam keadaan utuh, tidak rusak dan dalam jumlah yang cukup sehingga mudah ditemukan dalam pemeriksaan.

Infeksi kecacingan pada siswa SD Muhammadiyah Jampu Kecamatan Lanrisang Kabupaten Pinrang mempengaruhi pemasukan, pencernaan, penyerapan (absorbsi) serta metabolisme makanan sehingga menyebabkan kekurangan gizi. Siswa yang menderita kecacingan, nafsu 
makannya menurun sehingga makanan yang masuk akan berkurang dan jumlah cacing yang banyak dalam usus akan mengganggu pencernaan serta penyerapan makanan. Infeksi kecacingan selain berperan sebagai penyebab kekurangan gizi yang kemudian berakibat terhadap penurunan daya tahan tubuh terhadap infeksi, juga berperan sebagai faktor yang lebih memperburuk daya tahan tubuh terhadap berbagai macam infeksi.

Anak-anak Sekolah Dasar

Muhammadiyah Jampu Kecamatan Lanrisang Kabupaten Pinrang yang terinfeksi cacing mengalami penurunan kemampuan berfikir. Hasil studi menunjukkan penurunan kesehatan jasmani, pertumbuhan dan selera makan pada anak sekolah yang terinfeksi penyakit cacingan.

Penyakit kecacingan sering kali menyebabkan berbagai penyakit di dalam perut dan berbagai gejala penyakit perut seperti kembung dan diare. Cacing gelang tidak jarang menyebabkan kematian karena penyumbatan usus dan saluran empedu. Cacing juga dapat menyebabkan anemia berat yang mengakibatkan orang menjadi sangat lemah karena kehilangan darah. Infeksi kecacingan mempengaruhi pemasukan, pencernaan, penyerapan (absorbsi) serta metabolisme makanan sehingga menyebabkan kekurangan gizi. Anak yang menderita kecacingan, nafsu makannya menurun sehingga makanan yang masuk akan berkurang dan jumlah cacing yang banyak dalam usus akan mengganggu pencernaan serta penyerapan makanan.

Infeksi kecacingan selain berperan sebagai penyebab kekurangan gizi yang kemudian berakibat terhadap penurunan daya tubuh terhadap infeksi, juga berperan sebagai faktor yang lebih memperburuk daya tahan tubuh terhadap berbagai macam infeksi.

Hasil penelitian ini tidak sejalan dengan penelitian Pipit Festi (2015) dengan responden sebanyak 40 siswa Sekolah Dasar Al Mustofa Surabaya, hasil penelitiannya menyatakan bahwa didapatkan status gizi baik 53,3\% pemeriksaan cacingan negative $56 \%$, sebagaian tidak terkena cacingan $44 \%$. Hasil uji statistik didapatkan $\mathrm{p}=0,310$ berarti tidak ada hubungan antara status gizi dengan kejadian cacingan. ${ }^{9}$

\section{KESIMPULAN DAN SARAN}

Berdasarkan hasil penelitian dan pembahasan yang dilakukan mengenai status gizi hubungannya dengan penyakit kecacingan pada siswa SD Muhammadiyah jampu Kecamatan Lanrisang Kabupaten Pinrang maka diperoleh kesimpulan bahwa terdapat hubungan antara status gizi dengan penyakit cacingan pada siswa di SD Muhammadiyah Jampu. Penelitian ini menyarankan kepada pihak sekolah dan orang tua siswa lebih memperhatikan kebersihan makanan dan minuman siswa agar terhindar dari penyakit kecacingan serta memperhatikan pemakaian sandal saat keluar bermain, kepada orang tua 
siswa memberikan obat cacingan 6 bulan sekali sebagai bentuk pencegahan penyakit kecacingan dan kepada Pemerintah Kabupaten Pinrang melalui Dinas Kesehatan melakukan sosialisasi dan penyuluhan disetiap sekolah

\section{DAFTAR PUSTAKA}

1. Supariasa dkk. "Penilaian Status Gizi (Edisi Revisi). Jakarta: Penerbit Buku Kedokteran EGC; 2002.

2. Departemen Kesehatan Republik Indonesia. Riset Kesehatan Dasar. Jakarta: Badan Penelitian dan Pengembangan Kesehatan, Departemen Kesehatan, Republik Indonesia; 2007.

3. Departemen Kesehatan Republik Indonesia. Riset Kesehatan Dasar (Riskesdas). Badan Penelitian dan Pengembangan Kesehatan Kementerian RI tahun 2013; 2013. [Diakses pada tanggal 26 April 2018]

4. Rusmartini T. Penyakit oleh Cacing Usus. Dalam: Natadisastra D, Agoes R (eds). Parasitologi kedokteran: Ditinjau dari organ tubuh yang diserang. Jakarta: Penerbit Buku Kedokteran EGC; 2009 : pp: $72-84$

5. Andrauni, Adisti. Gambaran FaktorFaktor Penyebab Infeksi Cacingan pada Anak di SDN 01 Pasirlangu Cisarua. Bandung: Fakultas Ilmu Keperawatan dasar terkait dengan cara pencegahan dan bahaya infeksi penyakit cacingan sebagai upaya dalam meminimalisir kasus infeksi cacingan pada anak usia sekolah dasar.

Universitas Padjajaran; 2012. [Diakses pada tanggal 23 Maret 2018]. Available at:

http://www.journals.unpad.ac.id/index.php /ejournal/article/view/597.

6. I Wayan. Perangkat Pembelajaran Penjas, Olahraga dan Kesehatan. Jakarta: Azzahra Books; 2011. [Diakses pada tanggal 21 Maret 2018].

7. Behrman, Robert $\mathrm{M}$, Kliegman, Ann M.Arvin. Ilmu Kesehatan Anak Nelson. Jakarta: EGC; 2000: 3(15).

8. Wintoko, R. Hubungan Aspek Personal Hygiene dan Aspek Perilaku dengan Kontaminasi Telur Cacing pada Kuku Siswa Kelas 3,4 dan 5 di SDN 2 Rajabasa Kabupaten Bandar Lampung tahun ajaran 2012/2013. Bandar Lampung: Jurnal Kesehatan Unila; 2014: 4.

9. Pipit, Festi. Hubungan Status Gizi dengan Kejadian Penyakit Cacingan pada Siswa Sekolah Dasar Al Mustofa Surabaya”. Skripsi Universitas Muhammadiyah Surabaya; 2015. [Diakses pada tanggal 26 Maret 2018] 


\section{LAMPIRAN}

Tabel 1. Distribusi Karakteristik Responden Berdasarkan Jenis Kelamin dan Umur Responden di SD Muhammadiyah Jampu Kecamatan Lanrisang

\begin{tabular}{|c|c|c|}
\hline Karakteristik & Frekuensi (f) & Persentase $(\%)$ \\
\hline \multicolumn{3}{|l|}{ Jenis Kelamin } \\
\hline Laki-laki & 15 & 57,7 \\
\hline Perempuan & 11 & 42,3 \\
\hline \multicolumn{3}{|l|}{ Umur (Tahun) } \\
\hline 7 & 12 & 46,1 \\
\hline 8 & 6 & 23,1 \\
\hline 10 & 8 & 30,8 \\
\hline Total & 26 & 100 \\
\hline
\end{tabular}

Sumber: Data Primer, 2018

Tabel 2. Distribusi Status Gizi dan Penyakit Kecacingan pada Siswa SD Muhammadiyah Jampu Kecamatan Lanrisang

\begin{tabular}{lccc}
\hline & Variabel & f & \% \\
\hline Status Gizi & & & 73,1 \\
\hline Normal & & 19 & 26,9 \\
Kurus & 7 & \\
\hline Kecacingan & & 6 & 23,1 \\
\hline Positif & & 20 & 76,9 \\
Negatif & Total & $\mathbf{2 6}$ & $\mathbf{1 0 0}$ \\
\hline & &
\end{tabular}

Sumber: Data Primer, 2018 
Tabel 3. Distribusi Responden Berdasarkan Perilaku di SD Muhammadiyah Jampu Kecamatan Lanrisang Kabupaten Pinrang

\begin{tabular}{|c|c|c|}
\hline Perilaku Responden & $\mathrm{n}$ & Persentase $(\%)$ \\
\hline \multicolumn{3}{|l|}{ Konsumsi Air Minum Matang } \\
\hline YA & 22 & 84,5 \\
\hline TIDAK & 4 & 15,5 \\
\hline \multicolumn{3}{|l|}{ Konsumsi Obat Cacing 6 Bulan Sekali } \\
\hline YA & 8 & 30,9 \\
\hline TIDAK & 18 & 69,1 \\
\hline \multicolumn{3}{|c|}{ Orang Tua Memperhatikan Kebersihan Anak } \\
\hline YA & 23 & 88,2 \\
\hline TIDAK & 3 & 11,8 \\
\hline \multicolumn{3}{|l|}{ Tinggal di Wilayah Pesisir Pantai } \\
\hline YA & 13 & 50 \\
\hline TIDAK & 13 & 50 \\
\hline \multicolumn{3}{|l|}{ Berada di Lingkungan yang Bersih } \\
\hline YA & 14 & 53,6 \\
\hline TIDAK & 12 & 46,4 \\
\hline \multicolumn{3}{|c|}{ Selalu Mencuci Tangan Setiap Akan Makan dan Minum } \\
\hline \multicolumn{3}{|l|}{ YA } \\
\hline \multirow[t]{2}{*}{ TIDAK } & 26 & 100 \\
\hline & - & - \\
\hline \multicolumn{3}{|l|}{ Rutin Mengganti Pakaian Usai Beraktivitas } \\
\hline $\mathbf{Y A}$ & 21 & 80,9 \\
\hline TIDAK & 5 & 19,1 \\
\hline \multicolumn{3}{|l|}{ Mandi 2 Kali Sehari } \\
\hline YA & 24 & 92,8 \\
\hline TIDAK & 2 & 7,2 \\
\hline \multicolumn{3}{|c|}{ Memperhatikan Kebersihan Makanan dan Minuman } \\
\hline \multicolumn{3}{|c|}{ YA } \\
\hline \multirow[t]{2}{*}{ TIDAK } & 15 & 57,2 \\
\hline & 11 & 42,8 \\
\hline \multicolumn{3}{|l|}{ Memakai Sendal Saat Keluar Bermain } \\
\hline YA & 15 & 57,2 \\
\hline TIDAK & 11 & 42,8 \\
\hline \multicolumn{3}{|l|}{ Mencuci Tangan Setelah Bermain } \\
\hline YA & 20 & 76,3 \\
\hline TIDAK & 6 & 23,7 \\
\hline \multicolumn{3}{|l|}{ Memperhatikan Kebersihan Pakaian } \\
\hline YA & 19 & 73,7 \\
\hline TIDAK & 7 & 26,3 \\
\hline
\end{tabular}

Sumber: Data Primer, 2018 
Tabel 4. Hubungan Antara Status Gizi dan Penyakit Kecacingan di SD Muhammadiyah Jampu Kecamatan Lanrisang

\begin{tabular}{|c|c|c|c|c|c|c|c|}
\hline \multirow{3}{*}{ Penyakit Cacingan } & \multicolumn{4}{|c|}{ Status Gizi } & \multicolumn{3}{|c|}{ Total } \\
\hline & \multicolumn{2}{|c|}{ Kurus } & \multicolumn{2}{|c|}{ Normal } & \multirow{2}{*}{$\mathbf{n}$} & \multirow{2}{*}{$\%$} & \multirow{2}{*}{$P$} \\
\hline & $\mathrm{n}$ & $\%$ & $\mathrm{n}$ & $\%$ & & & \\
\hline Positif & 5 & 83,3 & 1 & 16,7 & 6 & 100 & \\
\hline Negatif & 2 & 10 & 18 & 90 & 20 & 100 & 0,001 \\
\hline Total & 7 & 26,9 & 19 & 73,1 & 26 & 100 & \\
\hline
\end{tabular}

Sumber: Data Primer, 2018 